\title{
Vaccine allied biologics
}

Volume 2 Issue 2 - 2016

\section{Ibrahim MSAW Shnawa \\ University of Qasim, Iraq}

\section{Letter to editor}

One of the themes that are longly born in mind, those concerning "Vaccine versus Probiotics". Then, if it is feasible to raise a question such as "Could we consider Probiotic as a vaccine, since they have an in-common indication, applications and/or attributes (Table 1). The common affairs are rather more than the different affairs. Thus, I think that they are forms of bio- therapeutics owning vaccine like potentials or one can say that they are vaccine-allied biologics.
Correspondence: Ibrahim MSAW Shnawa, College of Biotechnology, University of Qasim, Qasim, Babylon, Iraq, Email ibrahimshnawa3@gmail.com

Received: March 30, 2016 | Published: April 07, 2016

Table I Characteristics of vaccine versus probiotics

\begin{tabular}{|c|c|c|}
\hline Vaccines & Probiotics & Features \\
\hline Pathogens or their subunits & Certain commensal bacteria & Starter \\
\hline Specific in most cases & Nonspecific in most cases & Specificity \\
\hline Stringent for human favor & Less stringent for human favor & Evaluation attitude \\
\hline Needs special dispensing menu & Drug-like dispensing menu & Dispensing \\
\hline Specific mostly & Nonspecific, mostly & Specificity \\
\hline Immunoprphylaction & $\begin{array}{l}\text { Biotherapy of various immune defects in man } \\
\text { and animals }\end{array}$ & Indication \\
\hline Massive use rather than individual cases & On individual basis more than massive & Use \\
\hline $\begin{array}{l}\text { Infectious, epidemic and pandemic threat or on travel to epidemic } \\
\text { or endemic areas }\end{array}$ & Infectious and non-infectious & Disease nature \\
\hline Based on affinity of $B$ and $T$ memory cells & Bacteriocin, immunomodulatory, anticancerous & Mode of action \\
\hline Mild short duration like fever and ill & No appearent side effect & Side Effect \\
\hline Due to vaccine or host born causes & Due to probiotic or host born causes & Failure \\
\hline
\end{tabular}

\section{Acknowledgments}

None.

\section{Conflicts of interest}

Author declares there are no conflicts of interest.

\section{Funding}

None.

\section{References}

1. Banker DD. Modren Practice In Immunization. Popular Prakshan, Bombay, India. 1980. p.384.

2. Kaufmann SHE. Novel Vaccination Strategies. Wiley-VCH, Germany. 2004. p.670.

3. Kumar H, Salminen S, Vergagen H, et al. Probiotics and prebiotics road to market. Curr Opin Biotech . 2015;32:99-103.

4. Quigley EMM. Leaky gut-Concept or clinical entity. Curr Opin Gastroenterol. 2016;32(2):74-79. 